https://helda.helsinki.fi

\title{
REVOLUTION TALK AND MEDIA HISTORY
}

\author{
Kortti, Jukka
}

2021-05-30

Kortti , J 2021 , ' REVOLUTION TALK AND MEDIA HISTORY' , Academia Letters, vol. May 2021 , no. 811 . https://doi.org/10.20935/AL811

http://hdl.handle.net/10138/332507

https://doi.org/10.20935/AL811

cc_by

publishedVersion

Downloaded from Helda, University of Helsinki institutional repository.

This is an electronic reprint of the original article.

This reprint may differ from the original in pagination and typographic detail.

Please cite the original version. 


\title{
ACADEMIA $\mid$ Letters
}

\section{REVOLUTION TALK AND MEDIA HISTORY}

\author{
Jukka Kortti
}

Recent decades have faced the significant increase of media historical studies. The obvious reason for the contemporary popularity of media history studies is undoubtedly the need to understand our digital culture. One manifestation of the development is the increase of media history overviews published since the 1990s. The overviews often highlight the development of media as a series of "revolutions." Although the rise of propaganda in the forms of "trolling," "disinformation" and "post-truth politics" related to social media has stifled utopian digital revolution talk, it is alive and well especially in connection with algorithms, artificial intelligence, the Internet of things, and so on. For instance, the search words "digital revolution" get over 30,000 hits in JSTOR digital library.

Even more than usual, the historical context of a historian is crucial in interpreting media history. For instance, the rise of the media-deterministic Toronto School since the 1950s was a product of a new electronic age. Particularly television looked a "revolutionary" new media. Television was the Internet of the 60s: a "revolutionary mass media" and a McLuhanian "extension of man." 2 The father of the school, economic historian Harold A. Innis, looked at the entire history of civilization from the viewpoint of the history of media. According to Innis, communication tends to change political, juridical, religious and economic structures.

\footnotetext{
${ }^{1}$ On overviews, see e.g. Bill Kovarik, Revolutions in Communication: Media History from Gutenberg to the Digital Age (New York Continuum Books, 2011); Irving Fang, A History of Mass Communication: Six Information Revolutions (Burlington: Focal Press, 1997); Asa Briggs and Peter Burke, A Social History of the Media: From Gutenberg to the Internet (Cambridge: Polity, 2002), 15-73;David Crowley \& Paul Heyer (eds.)Communication in History: Technology, Culture, Society. Second Edition (New York: Longman Publishers, 1995). Revolution rhetoric was popular in media historical overviews already before the digital age. For instance, in the communication textbook Mass Communication, "communication revolution"' is as significant as the Industrial Revolution (Mary B. Cassata \& Molefi K. Asante, Mass Communication. Principles and Practices (New York \& London: Macmillan, 1979), 19.

${ }^{2}$ Marshall McLuhan, Understanding Media: The Extensions of Man (New York: Mentor, 1964).
}

Corresponding Author: Jukka Kortti, jukka.kortti@helsinki.fi

Citation: Kortti, J. (2021). REVOLUTION TALK AND MEDIA HISTORY. Academia Letters, Article 811. https://doi.org/10.20935/AL811. 
Especially empires - or the monopolies of power generally - are dependent on communication. $^{3}$

More than historians, those who have seen "profound changes," "sea changes," "far reaching implications," and "major shifts" toward a new era in contemporary communication environment have been social scientists, communication scholars and sociologists in particular. ${ }^{4}$ "The digital revolution" was an especially popular concept in the first decade of the new millennium. Information-society theoreticians often emphasized how new communication technologies dispel spatiality and temporality, make the world global and transform humans into a totally new social structure. For instance, one of the leading theoreticians of "the information age," sociologist Manuel Castells, sees in his massive The Information series a new digital revolution as a new paradigm in capitalistic media history, meaning that it is a new form of the old capitalism. ${ }^{5}$ The spread of the Internet and becoming into a "meta-media" and "a new media matrix " have evoked discussion about "a new epoch in media history."

The latest media revolution talk has concerned social media with algorithms, namely how they have radically changed human social intercourse and our sense of the world. The social media have also been seen as crucial factors in actual "old school" revolutions, especially in the Arab Spring of 2011, people communicating about the rallies and other agitation through social media during the unrest. ${ }^{7}$

However, the world became "networked" long before the Internet - at the latest, by the

\footnotetext{
${ }^{3}$ Harold A. Innis, Empire and Communications (Oxford: Clarendon Press 1950); Harold A. Innis, The Bias of Communications (Toronto: University of Toronto Press, 1951).

${ }^{4}$ Jim Macnamara, The 21st Century Media (R)evolution. Second Edition (New York: Peter Lang, 2013), 1011.

${ }^{5}$ Manuel Castells, The Information Age: Economy, Society and Culture. Volume 1. The Rise of the Network Society. Second Edition (Oxford: Blackwell, 2000); Manuel Castells, The Information Age: Economy, Society, and Culture. Volume 3. End of Millennium. Second Edition (Oxford: Blackwell, 2000); Manuel Castells, The Information Age: Economy, Society, and Culture. Volume 2. The Power of Identity. Second Edition (Oxford: Blackwell, 2005).

${ }^{6}$ See e.g. Nils Ole Finnemann, "Mediatization Theory and Digital," Communications, 36(1), 67-89.

${ }^{7}$ However, the role of social media in the Arab Spring has been over-emphasized in the West. A much more important medium was the ancient form of communication such as the outdoor meeting. For instance, people in Tahric Square in Cairo, Egypt were used to assembling in the square on Fridays. Accordingly, Arab journalist Emad Mekay (Emad Mekay, "Facebook's Arab Spring role was minimal,” SFGATE, January 15, 2012 https:/ /www.sfgate.com/opinion/article/Facebook-s-Arab-Spring-role-was-minimal-2519318.php ) emphasizes the significance of such outdoor meetings at the cost of social media, since only the government and journalists had access to the Internet. Moreover, the applications used were not Google, Facebook and Twitter, but rather the local iRevolt. After all, the Arab Spring was broadly linked to an "older" new media, such as satellite television, Internet access, and blogging (Leila Hudson, Adel Iskandar, and Mimi Kirk, Media Evolution on the Eve of the Arab Spring (New York: Palgrave Macmillan, 2014). In that sense, we can talk about the co-evolutionary dynamics of old and new media. (Finnemann, "Mediatization Theory and Digital," 85.)
}

Corresponding Author: Jukka Kortti, jukka.kortti@helsinki.fi

Citation: Kortti, J. (2021). REVOLUTION TALK AND MEDIA HISTORY. Academia Letters, Article 811. https://doi.org/10.20935/AL811. 
time telegraph networks spread globally in the British Empire in the late nineteenth century. Telephone lines also formed large networks. Before the computer-transmitted data network reached the consciousness of the general public, visions of interactive networks were associated with television. The telex, which was invented in the 1930s, but really only spread after the Second World War, was already quite close to the idea of the Internet.

But whereas the Arab Spring was seen, at least at the beginning of the unrest, as a positive manifestation of the "revolutionary" role of social media in our society and culture, the tone has radically changed since. Recent developments in the US with the Capitol Hill riots and the suspending of President Donald Trump's social media accounts have evoked harsh criticism on social media as well as on the Silicon Valley giants behind them.

However, the idea of seeing media development as a series of revolutions has been questioned by historians and theoreticians in various ways since the 1980s, when "the communication revolution" was increasingly associated with the rise of "the information society." Particularly media technology deterministic views were challenged. ${ }^{8}$ The utopian revolutionary talk of digital culture was increasingly criticized in the 2010s. For instance, technology critic Evgeny Morozov has questioned the visions and intentions of Californian Silicon Valley that promise that the revolution in online technologies will save the world. ${ }^{9}$ As sociologist Armand Mattelart writes: "The dictatorship of the short term certifies as genuinely new, and therefore revolutionary, changes that in fact testify to structural developments and processes that have been under way for a very long time."10

In terms of conceptual history, in the Middle Ages revolution meant the revolving motion of celestial bodies. When adapted to earthly use, it entailed a return to the original situation, a new start of the old in the historical continuum. Since the eighteenth-century Enlightenment, it started to mean fundamental changes in political power. The historical movement was central in the idea - that sudden, often violent changes can improve the sovereignty of citizens. The French Revolution, transformed the term in the interpretation and practice of modern politics.

Soon the notion of revolution in its modern sense started to be used on other occasions than political upheavals. One of the most important and studied metaphorical revolutions in modern history is, of course, the Industrial Revolution, which started in England in the mideighteenth century. The conceptual history of the Industrial Revolution originates from the early nineteenth century when contemporary French commentators started to see profound economic and social changes analogous to those that occurred in the French Revolution. The

\footnotetext{
${ }^{8}$ Denis McQuail, Mass Communication Theory: An Introduction. Third Edition (London: Sage, 1994), 87-93.

${ }^{9}$ Evgeny Morozov, To Save Everything, Click Here: The Folly of Technological Solutionism (London: Allen Lane, 2013).

${ }^{10}$ Armand Mattelart, The Information Society: An Introduction (London: Sage, 2003), 161.
}

Corresponding Author: Jukka Kortti, jukka.kortti@helsinki.fi

Citation: Kortti, J. (2021). REVOLUTION TALK AND MEDIA HISTORY. Academia Letters, Article 811. https://doi.org/10.20935/AL811. 
Industrial Revolution came into widespread use in the mid-nineteenth century. Among those who are considered to have made the term known are socialist philosopher Friedrich Engels and especially economic historian Arnold Toynbee, who emphasized not only mechanical inventions, the rise of market competition, the rapid population growth and changes in economic structure, but also the improvement of communication in his defining of the concept. ${ }^{11}$

Since the Industrial Revolution, the revolutionary rhetoric has been an integral part of the modern world of experience. A phenomenon akin to the Industrial Revolution that was predominantly cultural but also economic and social, was "the printing revolution."12 After the invention of printing, media have been distinctly modern. ${ }^{13}$ According to Reinhart Koselleck's well-known concept, revolution opened up a new horizon of expectation when enlighteners started to ask what will succeed revolution. The term included the idea of the future orientation that is separate from experiencing the present. Revolution led forward into an unknown future and became a metahistorical concept. As Koselleck puts it, "The concept of 'revolution' is itself a linguistic product of our modernity." 14

Modernity embraces changeability, dramatic breaks and, first of all, the idea of stepping forward to new potentialities and possibilities. Looking at the development of media from the nineteenth century onwards it is obvious that media have not only been integral part of the modernity, but have also accelerated the process of modernization and been an inspirational source and vehicle for modernism. In other words, media play a role in every dimension of modernity: diachronic (early, high and late modern), synchronous with its different modes (modernization, modernity and modernism), and a series of levels of the modern, meaning vertical social, cultural and subjective aspects of modern. ${ }^{15}$ The relationship between media and modernity becomes most tangible when innovation and novelty are discussed along with new media technologies. ${ }^{16}$

Revolution talk often has political and especially economic ulterior motives. Indeed, outwardly it gives reasons for the importance of investments and the decisions of the media in-

\footnotetext{
${ }^{11}$ Pat Hudson, The Industrial Revolution (London: Edward Arnold, 1992), 11.

${ }^{12}$ E.g. Elizabeth L. Eisenstein, The Printing Revolution in Early Modern Europe (Cambridge: Cambridge University Press, 1993).

${ }^{13}$ John B. Thompson, The Media and Modernity: A Social Theory of the Media (Stanford: Stanford University Press 1995), 23-47, 76-80.

${ }^{14}$ Koselleck, Futures Past, 43-57. About the concept of revolution, see also Hannah Arendt, On Revolution (New York: Viking Compass, 1965); John Dunn, "Revolution," in Political Innovation and Conceptual Change, ed. Terence Ball, James Farr \& Russell L. Hanson (Cambridge: Cambridge University Press, 1989), 333-356.

${ }^{15}$ Johan Fornäs, Cultural Theory and Late Modernity (London: Sage, 1995), 18, 32, 39-40.

${ }^{16}$ Tom Gunning, "Re-Newing Old Technologies: Astonishment, Second Nature, and the Uncanny in Technology from the Previous Turn-of-the-Century," inRethinking Media Change, ed. David Thorburn and Henry Jenkins (Cambridge and London: The MIT Press, 2004), 39-60.
}

Corresponding Author: Jukka Kortti, jukka.kortti@helsinki.fi

Citation: Kortti, J. (2021). REVOLUTION TALK AND MEDIA HISTORY. Academia Letters, Article 811. https://doi.org/10.20935/AL811. 
dustry. Not only is history forgotten, however, but the revolutionary character of the new technologies is also seasoned with innovation talk that is vital for twenty-first-century capitalism. ${ }^{17}$ Under cover of "revolution," the media industry can weaken working conditions or fire workers, for instance, as we have seen with the digital crisis of the press in the twentyfirst century. Nevertheless, such nightmare scenarios are by no means unique in the history of the press. For instance, in 1911, phonographic dictating machines (the Parlograph) began to replace the news journalist as the writing of stories diminished. Similar discussions have been ongoing in the 2010s concerning Stats Monkeys, namely journalist robots that can write sports and stock exchange news. ${ }^{18}$

When it comes to revolution talk in media history, it may be that we live in an extraordinary time, but I would argue that it is too early to say. When a future media historian makes a periodization in the $2100 \mathrm{~s}$, it is possible that our time will look like the end of an era rather than a new phase in human history. On the other hand, forecasts may prove too tame in the long run. ${ }^{19} \mathrm{http}: / /$ isen.com/archives/011126.html. As futurologist Roy Amaran has famously put it: "We tend to overestimate the effect of a technology in the short run and underestimate the effect in the long run." Yet my central idea in media history studies is to dispel the myth that we now live in an extraordinary time that has had no parallels in the history of media. I also see the ruptures and irregularities as important, often crucial factors for the development of media technologies. ${ }^{20}$

\footnotetext{
${ }^{17}$ David Edgerton, The Shock of the Old: Technology and Global History Since 1900 (London: Profile Books, 2008).

${ }^{18}$ See e.g. Rich Gordon, "Machine-Generated News a Threat to Journalists? I Think Not,"Mediashift, October 19, 2009 http://mediashift.org/2009/10/machine-generated-news-a-threat-to-journalists-i-think-not292/

${ }^{19}$ See, for instance, David S. Isenberg, "Amara's Law,"

${ }^{20}$ See Jukka Kortti, Media in History. An Introduction to the Meanings and Transformations of Communication over Time (London: Macmillan Red Globe Press, 2019).
}

Corresponding Author: Jukka Kortti, jukka.kortti@helsinki.fi Citation: Kortti, J. (2021). REVOLUTION TALK AND MEDIA HISTORY. Academia Letters, Article 811. https://doi.org/10.20935/AL811. 